\title{
Tractatus De matrimonio ad Robertum
}

\author{
Soňa Hudíková - Jana Malá \\ (Masaryk University, Brno)
}

\begin{abstract}
The aim of this article is to provide the Czech translation of a treatise of M. Jan Hus which was written (together with another six tractates) during his stay in Constance's jail. M. Jan Hus was asked by one of the gaolers named Robert to write something about marriage and marital status in general. In his treatise De matrimonio Hus gives instructions to Robert about what the marriage is, what the marriage was established for (by God), what are the main important reasons for getting married etc. Introduction preceding the translation of the Latin text is dedicated to a question how is the position of this tractate among the other treatises of Constance, and when this tractate was written. Furthermore there's shortly outlined its content, importance of this topic in Hus' work and its significance.
\end{abstract}

\section{Keywords}

Jan Hus; tractates of Constance; De matrimonio; marriage

This article was supported by Czech Science Foundation grant no. GA17-15433S "Jan Hus a husitská literatura pro 21. století". 
This short study is followed by a translation into Czech of Hus' tractate De matrimonio (with the incipit Petis, carissime, ut reputo), which was written together with six other tractates in Constance during the author's imprisonment. This concerns namely the following works: De mandatis Dei et de Oracione Dominica, De peccato mortali, De cognicione Dei, De tribus hostibus hominis, De penitencia, and finally De sacramento corporis et saguinis Domini.

All seven aforementioned tractates are the subject of a treatise written by V. Flajšhans in which the author tries to assess their textual tradition on the basis of comparing extant manuscripts together with the Relatio of Petr of Mladoňovice and the chronicle of Vavřinec of Březová. The tractate De matrimonio occupies the penultimate place in this list. ${ }^{1}$ At the beginning of the 20th century, all of these tractates were translated into Czech by M. Svoboda, who started the prologue preceding the Czech translation of De matrimonio with the words that the text was published in accordance with the previous Czech translation which was published ${ }^{2}$ in 1563 in Postilla. ${ }^{3}$ Nevertheless, we have decided to translate the tractate again because the existing one is already outdated and some of its passages might appear unclear and vague and unlike Svoboda we also used the Latin version of the tractate.

Jan Hus compiled De matrimonio in the jail of the monastery of the Dominican Order where he did not have any access to a library - he had no books at his disposal. Evidence of this fact can be seen in mentions in some manuscripts - that in the Prague National Library (signature V G 16) and that in the Austrian National Library in Vienna (signature 4524) as well as in the manuscript preserved in the Municipal Library of Bautzen (signature $\left.4^{\circ} 24\right)$ in which the tractate De matrimonio is always preceded by the following inscription: Tractatulos subsequentes, de quibus supra fit mencio, magister Iohannes Hus conpilavit in carceribus aput fratriculos Predicatores Constancie positus nullum librum habens in suffragium ad instantes preces custodum carceris predicti. De quibus custodibus ipse magister Iohannes Hus in fine tractatulorum metrice aliasve facit mencionem, et hoc anno Domini MCCCCXV in carnisprivio. Qui tractatuli ex originali manus sue presentibus sunt copiati et unus de manu eius hic alligatus est in memoriam eius. ${ }^{4}$ Editors hold the view that in this case these words must have belonged to Petr of Mladoňovice, who composed a work dealing with the end of John Hus' life. In spite of the fact those words cannot be found in either this work or his correspondence, they can be traced them back in the hyparchetype. ${ }^{5}$ Regarding the fact Hus had no books to support his thoughts, we can also read something in the very treatise De matrimonio, where Hus asserts that it was quite difficult for him to compose the treatise because of the insufficiency of his education together with his lack of books. ${ }^{6}$ With this declaration, Hus in fact supports a so-called topos modestiae, which was very common in his era, and tries to make clear that his intellectual potential is limited.

1 Flajšhans (1934).

2 Available on website http://www.etf.cuni.cz/library/Hus-Postilla/.

3 Svoboda \& Flajšhans (1904: p. 223).

4 The manuscript of the Municipal Library of Bautzen 4 24, f. 75r, see Krmíčková \& Nechutová (2016: pp. XXXIII-XXXIV).

5 See Krmíčková \& Nechutová (2016: p. XXXIV).

6 Hus, De matrimonio (Krmíčková \& Nechutová 2016: p. 171). 
There is no doubt about Hus' authorship of De matrimonio because this treatise is connected with his name in five manuscripts. ${ }^{7}$ The accepted date of origin can be found in one letter addressed to Jan of Chlum on 5 March 1415 where Hus writes that he "wrote one treatise concerning the body of Christ today and another concerning marriage yesterday and he asks John to have copies of them made". ${ }^{8}$ The tractate had been finished by 4 March, and although it was written primarily at the request of the gaoler Robert ${ }^{9}$ and for his personal use, Hus wanted it to be circulated. ${ }^{10}$ At Robert's request, Hus compiled some additional treatises, namely De peccato mortali ${ }^{11}$ and De sacramento corporis et saguinis Domini. ${ }^{12}$

In the treatise, Jan Hus, at Robert's request, has agreed to compile a short treatise concerning marriage. Therefore, he appeals to Robert to give some thought to questions related to marriage: first what marriage is, second what marriage was established by God for, third what the most substantial thing in marriage is, and lastly what the main reasons are to enter into marriage. Each of the aforementioned topics is later described in detail, one by one, with the most discussion devoted to the last. At the beginning, he describes the institution of marriage as a bond which is believed to be unbreakable by any man if there are no legitimate obstacles to entering marriage (e.g., blood relationships, a vow of chastity). According to Hus, marriage was conceived by God for these main purposes: parenting and avoiding temptation. While discussing the topic of the basic constitutive elements of marriage, Hus often quotes St. Augustine and follows his opinion that the main significance of marriage consists of proliferating and maintaining reciprocal marital fidelity and, finally, in accordance with Augustine also Hus designates marriage as a sacrament. At the end, Hus discusses reasons leading to entering into marriage and appeals to Robert to marry a woman not because of her beauty but because of her chastity and honesty; Robert's final choice should be made under the supervision of God. Hus also focuses his attention on some recommendations concerning marital intercourse.

Two Latin hexameters, part of the treatise, are dealt with in detail by Anežka Vidmanová-Schmidtová. ${ }^{13}$ She tried to come up with a solution to the problem of Hus' hexameters; this issue was the subject of a stormy discussion between Král and Flajšhans. ${ }^{14}$

7 Krmíčková \& Nechutová (2016: p. XLIX).

8 Hus, Korespondence (Novotný 1920: p. 250, č. 114): Hodie complevi unum tractatulum de corpore Christi, et heri unum de matrimonio; postea facietis copiare. See Krmíčková \& Nechutová (2016: p. XLIX).

9 Hus, De matrimonio (Krmíčková \& Nechutová 2016: p. 171): Petis, carissime, ut reputo, ad tui comodum aliquid tibi scribi de matrimonio...

10 See Molnár (1959: pp. 86-87).

11 Hus, De peccato mortali (Krmíčková \& Nechutová 2016: p. 140): Hec tibi, Roberte, sedens in carcere scripsi / ne ceterum iam te crimini suppedites ipsi.

12 Hus, De sacramento corporis et sanguinis Domini (Krmíčková \& Nechutová 2016: p. 185): Sepius rogasti, carissime, ut tibi aliquid de sacramento corporis et sanguinis Domini nostri Iesu Cristi scriberem... Proof of the fact that the tractates were addressed to Robert is given in the five verses concluding the text; see ibid. (Krmíčková \& Nechutová 2016: p. 209): Da, Deus, Roberto hec capere lumine certo...

13 Vidmanová-Schmidtová (1965); J. Nováková also mentioned Hus' verses in her article, see Nováková (1966).

14 Král (1893; 1898), Flajšhans (1898). 
In spite of the fact that the main topic of her study consists of hexametres and verses in Hus' Czech treatises, Vidmanová-Schmidtová first dealt with the Latin verses. ${ }^{15}$ In the foreword, she analysed the first of the hexameters which are to be found in De matrimonio and which were indisputably authored by Hus; we can count among them the following dedication located at the end of the text: Accipe, Roberte, hec dicta, accipe grate, / retinens iam per te, que celi, Domino da te, / qui tibi uxorem pulcram scit facere bonam, / reprimens fervorem luxus, quit tradere zonam. ${ }^{16}$ Vidmanová-Schmidtová analysed the meter of the verses and came to the conclusion that the verses are Leonine hexameters, but in composing those verses Hus committed some mistakes compared to the classic laws of meter and mixed the rhythmic and prosodic systems. ${ }^{17}$ There is another quatrain in Hus' treatise De matrimonio, which Vidmanová-Schmidtová used as the basis for her analysis of its Czech version: Quatuor ex causis tibi sit coniunccio carnis: / ut saciet, vitet, ut gignat, debitum solvat. / Primum mortale, sed reliquum est veniale, / sed duo postrema sunt prorsus et sine pena. ${ }^{18}$ Although Hus ${ }^{19}$ is not the author of the original Latin template, as even Vidmanová-Schmidtová admitted, according to her survey this template was composed in an identical way as Hus' own hexametres dating back to 1415; therefore, the aforementioned verses cannot be considered either purely prosodic or strictly rhythmic, but their structure is nevertheless hexametric. ${ }^{20}$ This means that Hus did not compose those verses himself but used the verse in his texts frequently ${ }^{21}$ and when composing these verses in the Czech language he followed the same principle of composition as the author of the Latin template:22 "Pro čtyři příčiny bývá muži poznánie ženy: / aby chlípnil, varoval, plodil, dluh zákona plnil. / Najprvý smrtedlný, druhý jest toliko všednie; / ale dva poslednie jsta bez smrti a viny všední." ${ }^{23}$ In most of the manuscripts, those verses are supplemented by interlinear glosses, the author of which - following the opinion of the authors of the modern edition of Constanciensia - is undoubtedly Hus himself, because some of the glosses belonging to the first hexameter can be found also in Hus' treatise Super IV Sentenciarum. ${ }^{24}$

In spite of the fact that Hus could not make use of even basic literature, we can track some of his sources back by analyzing merely his text. The main sources include the Bible, other excerpts are taken from patristic literature, and in numerous cases there are com-

15 Vidmanová-Schmidtová (1965: p. 158).

16 Hus, De matrimonio (Krmíčková \& Nechutová 2016: p. 181).

17 Vidmanová-Schmidtová (1965: pp. 160, 163).

18 Hus, De matrimonio (Krmíčková \& Nechutová 2016: pp. 176-177).

19 Other versions can be found (in various alterations) in the register Initia carminum of Hans Walther; see Walther (1959: 15290, 15300, and 15318).

20 Vidmanová-Schmidtová (1965: p. 165).

21 These verses can be found further in Hus' treatise De matrimonio (A), his commentary on the Sentences of Peter Lombard, and also the commentary on seventh chapter of the First Epistle to the Corinthians.

22 Vidmanová-Schmidtová (1965: p. 165).

23 Hus, Mravné průpovédi (Mistr Jan Hus. Drobné spisy české, 1985: p. 347, ed. J. Daňhelka, whose name couldn't be mentioned because of the communist regime in the country).

24 Krmíčková \& Nechutová (2016: p. L, note 93). 
mon Latin phrases. The fact the issues concerning marriage were of the greatest interest to Hus is evidenced by the fact that before the tractate of Constance called De matrimonio ad Robertum Hus had composed two other Latin treatises likewise called De matrimonio (A) with the incipit De quibus autem scripsistis michi: Bonum est homini mulierem non tangere and De matrimonio $(B)^{25}$ with the incipit De matrimonio restat modicum modo loqui et primo, quid sit, $2^{\circ}$, que sunt proprietates eius as well as the Czech treatise $O$ manželstvi. ${ }^{26}$ Hus discussed a similar topic also in his commentary on the Sentences of Peter Lombard ${ }^{27}$ as well as his commentary on the seventh chapter of the First Epistle to the Corinthians. ${ }^{28}$

As sufficient testimony of the treatise being widely spread can be considered its copies preserved in 24 manuscripts ${ }^{29}$ as well as its reworking into Provençal Yo entendo de dire; a comparison of these two treatises - Hus' De matrimonio and this Provençal text - was pursued by Amedeo Molnár, who provided evidence of literal correspondence between them. ${ }^{30}$ As Molnár described, there are some dissimilarities at the beginning of the two tractates: in the Waldensian version the first paragraph concerning Hus' imprisonment is missing and therefore this version starts with an outline of the structure Hus planned to follow while composing his tractate, i.e. by designating the questions of what marriage is, why it was established by God, and so on. As Molnár determined, both of the authors answered the question identically. The author of the Waldensian version moreover expounded on some of the biblical quotations which Hus only refered to, and to "explain using the proverbial expression about the rare bird which Hus uses as an allusion to the legendary Phoenix, as the Publisher of the Waldensian tractate does, is certainly superfluous". ${ }^{31}$ Further, Molnár also determined that the text of the tractate Yo entendo de dire includes a modified part of the beginning of the second part of Hus' treatise where he indicated four reasons for marital intercourse - the author of the Waldensian tractate noticed Hus' inconsistency in refering to the explanation of the aforementioned four reasons (he omitted one of them: ut saciet); he enumerated only three of them and distinguished them by the expressions convenivol, vana, and non convenivol, which terms are not in Hus' tractate. ${ }^{32}$ Molnár also provided other examples and came to the conclusion that the author of the Waldensian tractate Yo entendo de dire plentifully benefited from Hus' treatise De matrimonio and "merely left out the introductory and concluding sentences and all verses; in one place he changed Hus' tractate according to his own ideas; as a rule he elaborated Biblical and Deuterobiblical quotations..." 33

25 The titles are used in modern works for distinction of both tractates, see Bartoš \& Spunar (1965: pp. 65, $66)$.

26 The Latin tractates do not yet have a critical edition; one is being prepared. The Czech treatise $O$ manželstvi has been edited as a part of the series Mistr Jan Hus. Drobné spisy české (1985: pp. 297-311).

27 Krmíčková \& Nechutová (2016: p. XLIX).

28 Hus, Explicatio in VII. caput epistolae ad Corinthios (Flaccius Illyricus 1558: f. 100r-104v).

29 Krmíčková \& Nechutová (2016: p. L).

30 Molnár (1958) and Molnár (1959).

31 Molnár (1958: p. 144).

32 Molnár (1958: p. 144).

33 Molnár (1958: p. 145). 
Our translation is based on the critical edition of the text published recently in the series Corpus Christianorum. Continuatio Medievalis from Brepols Publishers. ${ }^{34}$

Součástí této studie je překlad Husova traktátu De matrimonio s incipitem Petis, carissime, ut reputo, jenž vznikl spolu $\mathrm{s}$ dalšími šesti traktáty v Kostnici během Husova věznění v žaláři. Jedná se konkrétně o tato díla: De mandatis Dei et de Oracione Dominica, De peccato mortali, De cognicione Dei, De tribus hostibus hominis, De penitencia a konečně De sacramento corporis et saguinis Domini.

Těmto traktátům se ve své studii podrobně věnoval Václav Flajšhans, jenž na základě srovnání jednotlivých dochovaných rukopisů, dále pak díla Relatio Petra z Mladoňovic a kroniky Vavřince $\mathrm{z}$ Březové stanovuje pořadí jejich vzniku. Náš spisek klade $\mathrm{v}$ časové posloupnosti na předposlední místo. ${ }^{35}$ Na počátku 20 . století byly zmíněné traktáty Milanem Svobodou přeloženy do češtiny; v úvodu k překladu spisku $O$ manželstvi uvádí, že byl „otištěn podle starého překladu českého, r. 1563 v Postille ${ }^{36}$ poprvé vydaného “ ${ }^{37}$ Přesto jsme se rozhodly tento traktát znovu přeložit, na rozdíl od M. Svobody jsme vycházely z latinského traktátu.

Mistr Jan Hus sepsal tento traktát v žaláři u dominikánů bez možnosti nahlížet do jakékoli literatury, což dokládá zmínka v rukopisech Národní knihovny v Praze (sign. V G 15), Österreichische Nationalbibliothek ve Vídni (sign. 4524) a v rukopise uloženém v Městské knihovně v Budyšíně (sign. 40 24), v nichž je před spisem De matrimonio následující prrípisek: Tractatulos subsequentes, de quibus supra fit mencio, magister Iohannes Hus conpilavit in carceribus aput fratriculos Predicatores Constancie positus nullum librum habens in suffragium ad instantes preces custodum carceris predicti. De quibus custodibus ipse magister Iohannes Hus in fine tractatulorum metrice aliasve facit mencionem, et hoc anno Domini $M C C C C X V^{\circ}$ in carnisprivio. Qui tractatuli ex originali manus sue presentibus sunt copiati et unus de manu eius hic alligatus est in memoriam eius. ${ }^{38}$ Editoři vyslovují názor, že se v tomto př́padě musí jednat o slova Petra z Mladoňovic, jenž sepsal dílo o Husově životě zvané Relatio, ačkoli je nenalezneme ani v tomto díle ani v jeho korespondenci - byla zřejmě součástí hyparchetypu. ${ }^{39} \mathrm{O}$ skutečnosti, že Hus neměl po ruce žádné knihy jako oporu pro své úvahy, se dočteme i v pojednání De matrimonio, kde Hus označuje sepsání tohoto traktátu za nesnadný úkol, v němž mu brání nejen nepatrnost jeho nadání, ale právě i nedostatek knih. ${ }^{40}$ Tímto výrokem Hus v zásadě podpořil v dané době obvyklý topos modestiae, jímž vyjadřuje svou intelektuální nedostatečnost.

34 Krmíčková \& Nechutová (2016: pp. 169-181).

35 Flajšhans (1934).

36 Dostupné na adrese: http://www.etf.cuni.cz/library/Hus-Postilla/.

37 Svoboda \& Flajšhans (1904: p. 223).

38 Rukopis Městské knihovny v Budyšíně 4² 24, f. 75r, srv. Krmíčková \& Nechutová (2016: pp. XXXIIIXXXIV).

39 Srv. Krmíčková \& Nechutová (2016: p. XXXIV).

40 Hus, De matrimonio (Krmíčková \& Nechutová 2016: p. 171). 
O autentičnosti Husova autorství není pochyb, poněvadž s jeho jménem je tento traktát spojen celkem v 5 rukopisech. ${ }^{41} \mathrm{O}$ době vzniku tohoto spisku se dozvídáme z listu, který Hus 5. března 1415 adresoval Janovi z Chlumu a v němž Hus uvádí, že „dnes sepsal jeden traktátek o těle Kristově a včera jeden o manželství, a ukládá Janovi, aby je rozmnožil“. ${ }^{42}$ Traktát tedy vznikl 4 . března, a i když tento text byl sepsán na žádost a pro potřebu žalářníka Roberta, ${ }^{43}$ záleželo Husovi na jeho dalším rozšíření. ${ }^{44} \mathrm{Na}$ popud zmíněného žalářníka Hus sestavil i další traktáty, jmenovitě De peccato mortali ${ }^{45}$ a De sacramento corporis et saguinis Domini. ${ }^{46}$

Hus se v traktátku na prosbu žalářníka Roberta ujímá úkolu napsat krátké pojednání o manželství, přičemž vyzývá Roberta, aby se on sám zamyslel nad čtyřmi otázkami souvisejícími s manželstvím, tedy zaprvé nad tím, co manželství je, za druhé z jakého důvodu jej Bůh ustanovil, za třetí co je v něm podstatné a konečně za čtvrté jaké hlavní důvody vedou k rozhodnutí manželství uzavřít. Hus postupně tyto otázky rozvíjí, nejvíce se přitom věnuje otázce čtvrté. Nejprve tedy definuje instituci manželství jako pouto, které člověk nemůže svévolně rozvázat a zrušit, pakliže uzavření sňatku nebrání nic, co by bylo možno považovat za nelegitimní (tj. kupříkladu pokrevní příbuzenství, sliby čistoty nebo jiné překážky). Dále uvádí, že Bůh ustanovil manželství za účelem plození potomstva a ochrany před vnějšími svody k hříchu. Ve výkladu o tom, co je v manželství podstatné, si Hus bere na pomoc sv. Augustina, podle nějž je to především zplození potomstva, zachovávání vzájemné věrnosti a v neposlední řadě považuje manželství za svátost. Nakonec se věnuje tomu, jaké důvody by měly vést $\mathrm{k}$ uzavření manželství, vyzývá Roberta, aby si vzal ženu ne pro její krásu, ale pro její čistotu a poctivost, a aby se při jejím výběru spolehl na Boha. Velký prostor pak zaujímají doporučení týkající se tělesné lásky mezi manželi.

Součástí textu jsou i dva latinské hexametry, jimiž se ve svém článku blíže zabývala Anežka Vidmanová-Schmidtová. ${ }^{47}$ Ta se pokusila přinést řešení v otázce hexametrů u Husa, jež vyvolala ostrou diskusi mezi Králem a Flajšhansem. ${ }^{48}$ I když předmětem studie jsou především hexametry a verše v Husových českých spisech, vychází Anežka Vidmanová-Schmidtová nejprve z jeho veršů latinských. ${ }^{49} \mathrm{~V}$ tomto úvodu se kromě jiných

41 Krmíčková \& Nechutová (2016: p. XLIX).

42 Hus, Korespondence (Novotný 1920: p. 250, č. 114): Hodie complevi unum tractatulum de corpore Christi, et heri unum de matrimonio; postea facietis copiare. Srv. Krmíčková \& Nechutová (2016: p. XLIX).

43 Hus, De matrimonio (Krmíčková \& Nechutová 2016: p. 171): Petis, carissime, ut reputo, ad tui comodum aliquid tibi scribi de matrimonio...

44 Srv. Molnár (1959: pp. 86-87).

45 Hus, De peccato mortali (Krmíčková \& Nechutová 2016: p. 140): Hec tibi, Roberte, sedens in carcere scripsi / ne ceterum iam te crimini suppedites ipsi.

46 Hus, De sacramento corporis et sanguinis Domini (Krmíčková \& Nechutová 2016: p. 185): Sepius rogasti, carissime, ut tibi aliquid de sacramento corporis et sanguinis Domini nostri Iesu Cristi scriberem,... Fakt, že se jedná o Roberta, potvrzuje závěrečné pětiverší na konci traktátu, srv. tamtéž (Krmíčková \& Nechutová 2016: p. 209): Da, Deus, Roberto hec capere lumine certo...

47 Vidmanová-Schmidtová (1965); Husovy verše obsažené v tomto traktátu zmiňuje ve svém článku i J. Nováková, srv. Nováková (1966).

48 Král (1893; 1898); Flajšhans (1898).

49 Vidmanová-Schmidtová (1965: p. 158). 
věnuje prvnímu z hexametrů nacházejících se v traktátu De matrimonio, jež jsou vlastním dílem Mistra Jana Husa. Jedná se o dedikační formuli na konci textu: Accipe, Roberte, hec dicta, accipe grate, / retinens iam per te, que celi, Domino da te, / qui tibi uxorem pulcram scit facere bonam, / reprimens fervorem luxus, quit tradere zonam. ${ }^{50}$ Anežka Vidmanová-Schmidtová provádí metrický rozbor těchto veršů a dochází k názoru, že se jedná o leoninské hexametry, Hus se však při jejich skládání dopustil prohřešků vůči klasické časomíře a smísil v nich časomíru s přízvukem. ${ }^{51}$ Další čtyřverší: Quatuor ex causis tibi sit coniunccio carnis: / ut saciet, vitet, ut gignat, debitum solvat. / Primum mortale, sed reliquum est veniale, / sed duo postrema sunt prorsus et sine pena, ${ }^{52}$ jež se nachází v Husově traktátu De matrimonio, užívá Anežka Vidmanová-Schmidtová jako podklad pro rozbor české podoby těchto hexametrů. I když autorem latinské předlohy není Hus, ${ }^{53}$ jak sama Anežka Vidmanová-Schmidtová přiznává, je dle jejího zjištění však tvořena stejným zpơsobem jako Husovy vlastní hexametry z r. 1415, nejedná se tedy ani o čistě časoměrné ani o čistě přízvučné verše, zachovávají však strukturu hexametru. ${ }^{54}$ Hus tedy tyto verše sám nevytvořil, ale hojně je ve svých textech využíval ${ }^{55}$ a při tvorbě jejich české podoby se držel stejného principu jako autor jejich latinské předlohy: ${ }^{56}$ „Pro čtyři příčiny bývá muži poznánie ženy: / aby chlipnil, varoval, plodil, dluh zákona plnil. / Najprvý smrtedlný, druhý jest toliko všední; / ale dva poslednie jsta bez smrti a viny všední. “57 Ve většině rukopisů jsou tyto verše opatřeny interlineárními glosami, jejichž autorem je dle autorů moderní edice kostnických traktátů nepochybně Hus, protože část glos u prvního hexametru se již objevuje v jeho práci Super IV Sentenciarum..$^{58}$

I když Hus neměl k dispozici žádné knihy, můžeme se na základě textu dopátrat jeho pramenů, z nichž nejdůležitějším je zejména Bible. Najdeme zde i úryvky z církevních Otců, jedná se však o všeobecné citace. Hus věnoval problematice manželství velkou pozornost, kostnickému traktátu De matrimonio ad Robertum totiž předcházela další dvě latinská díla zabývající se manželstvím zvaná rovněž De matrimonio $(A) \mathrm{s}$ incipitem $D e$ quibus autem scripsistis michi: Bonum est homini mulierem non tangere a De matrimonio $(B)^{59} \mathrm{~s}$ incipitem De matrimonio restat modicum modo loqui et primo, quid sit, $2^{\circ}$, que sunt proprietates

50 Hus, De matrimonio (Krmíčková \& Nechutová 2016: p. 181).

51 Vidmanová-Schmidtová (1965: pp. 160, 163).

52 Hus, De matrimonio (Krmíčková \& Nechutová 2016: pp. 176-177).

53 Její znění lze najít (v několika různých modifikacích) v soupisu Initia carminum Hanse Walthera, srv. Walther (1959: 15290, 15300 a 15318).

54 Vidmanová-Schmidtová (1965: p. 165).

55 Najdeme je dále v Husově traktátu De matrimonio (A), v jeho výkladu Sentencí Petra Lombardského a také ve výkladu sedmé kapitoly Prvního listu Korintským.

56 Vidmanová-Schmidtová (1965: p. 165).

57 Hus, Mravné průpovědi (Mistr Jan Hus. Drobné spisy české, 1985: p. 347, ed. J. Daňhelka, jehož jméno nemohlo být kvůli komunistickému režimu zmíněno).

58 Krmíčková \& Nechutová (2016: p. L, pozn. 93).

59 Tyto názvy se užívají v moderních studiích pro odlišení obou traktátů; srv. Bartoš \& Spunar (1965: pp. 65, $66)$. 
eius a český spisek $O$ manželstvi ${ }^{60}$ Obdobnou problematikou se Hus zabýval i ve výkladu Sentencí Petra Lombardského ${ }^{61}$ či ve výkladu k Prvnímu listu Korintským. ${ }^{62}$

O rozšíření a recepci tohoto spisku svědčí nejen jeho dochování v 24 rukopisech, ${ }^{63}$ ale i jeho převod do provensálštiny Yo entendo de dire; srovnáním těchto dvou spisků se zabýval Amedeo Molnár, který dokazuje, že se obě díla z velké části doslovně shodují. ${ }^{64} \mathrm{Jak}$ Molnár uvádí, liší se začátek obou traktátů, ve valdenské verzi totiž chybí první odstavec odkazující na Husovo uvěznění v žaláři, valdenské zpracování tedy začíná až nastíněním osnovy traktátu, které se Hus hodlal při výkladu držet, tedy nastolením otázek, co je to manželství, proč bylo Bohem ustanoveno atd. Dle Molnárova zjištění odpovídají oba autoři na tuto otázku shodně, autor valdenského zpracování tu jen rozvádí některé biblické pasáže, na něž Hus jen odkazuje, a „zbytečně vyložil na báječného Foinixe Husovo užití příslovečného výroku o vzácném ptáku“. ${ }^{65}$ Dále Molnár zjištuje, že v textu Yo entendo de dire je upraven začátek druhé části Husova spisu, v němž Hus uvádí čtyři důvody pro manželské spojení, autor valdenského zpracování si totiž všiml Husovy nedůslednosti ve výkladu těchto čtyř důvodů, jenž o jednom z nich (ut saciet) pomlčel, zůstal proto raději pouze u třech důvodů a odstupňoval je označením convenivol, vana, non convenivol, které se v Husově traktátu nevyskytují. ${ }^{66}$ Molnár pak uvádí další příklady a dochází ke zjištění, že autor valdenského traktátu Yo entendo de dire hojně využil Husova spisu De matrimonio, přičemž vynechal úvodní a závěrečné věty a všechny verše, jedno místo upravil dle svého a dále rozvedl biblické citáty. ${ }^{67}$

Při překladu jsme vycházely z moderní edice tohoto textu, jež byla vydána v ediční řadě Corpus Christianorum. Continuatio Medievalis v nakladatelství Brepols teprve nedávno. ${ }^{6}$

\section{Jan Hus}

\section{O manželství}

Přál sis, můj milý, jak si vzpomínám, abych pro tvoji potřebu sepsal něco o manželství, do kterého chceš dle svých slov zakrátko vstoupit, bude-li to vůle Boží. Žádáš zajisté o věc dobrou, ušlechtilou, posvátnou a prospěšnou, avšak pro mne nesnadnou: jednak proto, že by výklad o stavu manželském byl velmi obšírný, pak také proto, že mi v tom brání nepatrnost mého nadání, jíž nemohu vypomoci v nynější vězeňské izolaci ani berličkou knih.

60 Latinské traktáty nebyly dosud vydány, kritická edice se připravuje. Český spisek $O$ manželstvi vyšel v rámci díla Jan Hus. Drobné spisy české (1985: pp. 297-311).

61 Krmíčková \& Nechutová (2016: p. XLIX).

62 Hus, Explicatio in VII. caput epistolae ad Corinthios (Flaccius Illyricus 1558: f. 100r-104v).

63 Krmíčková \& Nechutová (2016: p. L).

64 Molnár (1958) a Molnár (1959).

65 Molnár (1959: pp. 88-89).

66 Molnár (1959: p. 89).

67 Molnár (1959: p. 89).

68 Krmíčková \& Nechutová (2016: pp. 169-181). 
Aby se však tvé náležité žádosti nedostalo úplného odmítnutí, opravdu důkladně popřemýšlej o tomto: co je to manželství, proč bylo od Boha ustanoveno, co je v manželství podstatné a co tě k rozhodnutí uzavřít sňatek vede především.

Co se toho prvního týká, tedy věz, že manželství je nerozlučné pouto, a to takové, že pokud se ty, jakožto legitimní osoba, souhlasným prohlášením proneseným v dané chvíli s legitimní manželkou spojíš, nebudeš se moci tohoto závazku až do smrti její či své vlastní zprostit, abys mohl vstoupit do jiného zákonného svazku. Toto je zřejmé z výroku Kristova v 19. kapitole Matoušova evangelia, ${ }^{69}$ jenž zákoníkům a farizeům na jejich dotaz, zda je dovoleno manželku propustit z jakéhokoli malicherného důvodu, odpověděl, že to dovoleno není, jedině pro smilstvo. Z rozhodnutí církve lze manželku propustit, pokud jde o sdílení lože, není však na základě tohoto rozhodnutí možné vzít si za manželku jinou ženu nebo se s jinou ženou spojit, dokud ona žije. Je to zřejmé z toho, co praví Apoštol v 7. kapitole prvního listu Korintským. ${ }^{70}$

Povšimni si, že jsem řekl „legitimní osoba“, tedy taková, která je způsobilá k uzavření manželství s další osobou, neníli tu žádná překážka z minulosti, tedy nebrání-li ani slib zdrženlivosti, ani pokrevní příbuzenství nebo jiný druh spřízněnosti ${ }^{71}$ nebo překážka jiné povahy, aby bylo možné s touto osobou uzavřít řádný sňatek.

Co se týká toho druhého, vezmi na vědomí, že Bůh ustanovil v ráji manželství za účelem plození potomstva, když ve 3. kapitole Genese při zasnoubení Evy Adamovi řekl: „Plod'te a množte se. “72 Mimo ráj je pak manželství určeno k plození dětí a jako prostředek proti chtíči: k plození potomstva - jak pravil Pán po potopě Noemovi, jeho manželce a jejich potomkům: „Plod'te a množte se a naplňte zemi““;3 jako prostředek proti chtíči, tedy k tomu, aby se lidé vystříhali smilstva a krotili své touhy: tyto důvody k uzavření manželství uvádí Apoštol v 7. kapitole prvního listu Korintským, když říká: „Každý necht̉ má svou vlastní manželku kvůli smilstvu (rozuměj, aby ses ho vyvaroval) a každá at má vlastního muže, ${ }^{74}$ poněvadž je lepší žít v manželství než se trápit“75 nepřípustnou vášní mimo manželství.

Nuže, tady vidíš dva hlavní důvody, proč vstupovat do manželství, a tyto měj na paměti, abys pochopil, že plození potomstva a vyhýbání se smilstvu jsou v manželství výhodné.

$\mathrm{K}$ tomu třetímu považ, že podle mínění sv. Augustina patří k manželství tři věci, tedy potomstvo, věrnost a svátost. ${ }^{76}$ Potomstvo, které mají manželé vychovávat ke slávě Boží. Věrnost, tedy oddanost, kterou mají neochvějně zachovávat, svátost, kterou je zapotřebí zbožně a pokorně ctít.

To měj na mysli, můj milý, abys potomstvo plodil a vychovával, abys své choti zachovával naprostou věrnost a skrze své manželství abys zbožně a pokorně choval v úctě svazek Krista a jeho nevěsty církve. Svátostí je manželství proto, že je znakem posvátné věci: značí totiž spojení

69 Mt 19, 3.9.

70 Srv. $1 \mathrm{~K} 7,10-11$.

71 Lat. affinitas. Jedná se o nepokrevní příbuzenství, tedy švagrovství.

72 Gn 1, 28.

73 Gn 9, 1.

$74 \quad 1 \mathrm{~K} 7,2$.

$751 \mathrm{~K} 7,9$.

76 Augustinus, Gen. ad litt. 9, 7 (jedná se o výklad 1. knihy Mojžíšovy). 
Krista s církví. „Je to velké tajemství“, jak praví Apoštol v 5. kapitole listu Efezským, ${ }^{77}$ „které vztahuji na Krista a církev“. Proto také tamtéž říká: „Muži, milujte své ženy, jako si Kristus zamiloval církev a sám se za ni obětoval, aby ji posvětil." ${ }^{78}$ Muži tedy mají milovat své manželky, aby je posvěcovali, jako Kristus miloval církev, nikoli k jejich zneuctění a ze smyslnosti. Muži mají také milovat své manželky za účelem plození potomstva, jako Kristus miloval církev za účelem duchovního plození synů církve. A mají je milovat ctnostně, a díky tomu s nimi mohou žít v manželství zbožně, náležitě pečovat o rodinu a po smrti dosáhnout věčného života ve slávě.

Na to, můj milý, mysli a snaž se, aby tvoje manželství, které je znakem, odpovídalo svaté věci, jež je jím označována a jíž je spojení Krista ženicha s jeho nevěstou církví; ta byla totiž vytvořena z otevřené rány v boku Krista spícího na kř́žzi spánkem smrti tak, jako z boku spícího Adama byla stvořena jeho chot Eva. ${ }^{79}$

Za čtvrté, tedy pokud jde o to, co tě nejvíce vede ke vstupu do manželství, pečlivě rozvaž, at do něj nevstupuješ jinudy než skrze Ježíše Krista, těsnou bránu, abys nebyl jako zloděj a lupič ${ }^{80}$ a nevstupoval do manželství ze zcela jiných důvodů než z těch, které ustanovil Kristus Pán.

Řekl jsem tedy, že důvody k uzavření manželství, jak je zjevil Bůh, jsou plození potomstva a vyhýbání se smilstvu. Zejména toto uchovej ve své mysli spolu s pokornou úctou ke svátosti. Necht̉ pro tebe není hlavní pohnutkou ke vstupu do manželství ani ženská krása, která podněcuje chtíč a rozmařilost, ani urozenost, jež rozněcuje pýchu, ani bohatství nebo majetek, který svádí k lakotě; kéž hlavní místo ve tvé mysli vždy zaujímá čestnost a poctivost, které přispívají ke zdrženlivosti v manželství a činí z něj u Boha i u lidí chvályhodné počínání.

Možná namítneš: Kde mám najít poctivou ženu, když je to vzácný ptáček a je těžké jej rozpoznat? Můj milý, odpověd je nasnadě. Nebot jak říká Jakub, bratr Páně, ve své epištole: „Každý dobrý dar a každé dokonalé obdarování je shůry, sestupuje od Otce nebeských světel“", ${ }^{81}$ to jest, má přičinu v Bohu, který dává světlo světu. Jelikož dobrá žena je dokonalý dar, plyne z toho, že ona je darem Božím. Chcešli tedy mít dobrou ženu, „boj se Boha, zachovávej jeho přikázáni““82 a pros ho pokorně, a on ti dobrou ženu dá. Nebot’ on je ten, který spojuje tak, aby člověk nerozlučoval ty, které On spojil. ${ }^{83}$ On dal Adamovi Evu, ${ }^{84}$ Abrahamovi Sáru ${ }^{85}$ Elkánovi Chanu, ${ }^{86}$ Tobiášovi Sáru ${ }^{87}$ a Zachariášovi Alžbětu, ${ }^{88}$ a ty porodily svaté syny. Svěř i ty své úvahy Bohu, který neopouští ty, již v něj doufají, ${ }^{89}$ který skrze anděla zasnoubil svatému Tobiášovi krásnou a svatou

Ef 5,32 .

$81 \mathrm{Jk} 1,17$.

82 Kaz 12, 13.

83 Srv. Mt 19, 6; Mk 10, 9.

84 Srv. Gn 2, 22-23.

85 Srv. Gn 11, 29.

86 Srv. $1 \mathrm{Kr}$ 1, 1-2.

87 Srv. Tób 10, 10.

88 Srv. Lk 1, 5.

89 Srv. Júd 13, 17. 
Sáru. Démon Asmodaj, veden zvrácenou láskou k její kráse, zahubil postupně všech jejích sedm mužů vždy na počátku svatební noci, neuškodil však svatému Tobiášovi, poněvadž ten si ji vzal za manželku nikoli veden chtíčem, ale kvůli plození potomstva, nebot se řídil radami anděla. ${ }^{90}$ Dále pak věz, můj milý, že manželé spolu tělesně obcují z těchto čtyř důvodů: zaprvé kvůli potomstvu, jak ustanovil Bůh, ${ }^{91}$ zadruhé pro potlačení smilstva a pokušení, zatřetí jako plnění vzájemné povinnosti. ${ }^{92}$ Tyto dva důvody uvádí Apoštol v sedmé kapitole prvního listu Korintským. Proto jsou tyto čtyři důvody, třebaže ne ve stejném pořadí, vyjádřeny v těchto verších: ${ }^{93}$

Jsou zde důvody čtyři, proč tělesně obcovat můžeš:

aby ses ukojil, nezhřešil, plodil a povinnost splnil.

To první je těžkým hříchem, to druhé hříchem jen lehkým,

ale ty na konci uvedené jsou bez trestu zcela. ${ }^{94}$

Prvního př́ípustného spojení se týká toto: Plod'te a množte se,$^{95}$ tedy v dovoleném spojení kvưli potomstvu. O druhém, tedy o vystř̌ihání se hříchu, mluví Apoštol takto: Každý z vás at má svou vlastní manželku kvưli smilstvu, tedy aby se jej vystříhal. ${ }^{96} \mathrm{O}$ třetím říká Apoštol tamtéž, v sedmé kapitole prvního listu Korintským: Manželka at prokazuje muži, čím je mu povinna, a muž manželce. ${ }^{97}$ Čtvrté spojení zakazuje Boží přikázání ve 22. kapitole Exodu: „Nesesmilnís “98 - tímto se zakazuje každé nedovolené a zapovězené spojení, které člověka zbavuje Boží lásky.

Toto měj často před očima, můj milý, abys věděl, jak si máš v manželství počínat, abys byl milý Bohu a prospěšný sobě. Když ti Bůh dá manželku, tedy po uzavření obvyklého církevního svazku neboli po sňatku, setrvej v modlitbách se svou chotí po tři noci, teprve čtvrtou noc vejděte spolu na lože, abyste v bázni Boží plodili potomky, jako to poradil anděl Tobiášovi. ${ }^{99}$

Dále pak nikdy nevstupuj k menstruující choti, protože to Pán zakázal v 18. kapitole knihy Ezechiel. ${ }^{100}$ Vyhýbej se i ženě těhotné, co nejvíce a nejdéle můžeš. V době po porodu čili v šestinedělí se také zdrž styku. Dny sváteční a postní oslav zdrženlivostí. Tak totiž učí svatí, obzvláště sv. Augustin v kázání o manželství. ${ }^{101}$

Vystřríhej se také, můj milý, jakéhokoliv zneužití své manželky, všech nedovolených doteků, jednej s ní uctivě, aby i ona tě měla v úctě a aby uměla, dle výroku Apoštola, žít se svým mužem

90 Tób 3, 8-11; 6, 11-20; 8, 1-15.

91 Srv. Gn 1, 28.

$92 \quad 1 \mathrm{~K} 7,2-3$.

93 Srv. Walther (1959: 15290, 15300, 15318). V textu za tímto čtyřverším následují vysvětlivky k různým výrazům: aby ses ukojil = chtíč, abys nezhřešil $=$ smilstvem, abys plodil $=$ syny, povinnost $=$ zákonnou, abys splnil $=$ choti, zcela $=$ smrtelného, trestu $=$ zatracení.

94 Překlad Jana Nechutová.

95 Gn 1, 28.

96 Srv. $1 \mathrm{~K} 7,2$.

97 Srv. $1 \mathrm{~K} 7,3$.

98 Ex 20, 14.

99 Srv. Tób 6, 18-22.

100 Srv. Ez 18, 6.

101 Aug., Serm. 216, 3. 
svatě a s úctou. Apoštol totiž říká: „Každý z vás, bratři, at umí žít se svou vlastní ženou svatě a s úctou. " 102

Střez se styku s cizími ženami, aby tě vlastní žena nepodezřívala, neměla tě méně ráda, nezačala tě nenávidět a nepřinesla neklid tobě a celé rodině.

Vyhni se vášnivé lásce, to jest silné a přehnané náklonnosti k manželce, protože každý vášnivec je neřádným milencem své manželky a podle sv. Jeronýma je to cizoložník. ${ }^{103}$ Tento výrok lze snad chápat tak, že hřeší jako by se dopouštěl cizoložství, nebo jej snad lze chápat příhodněji tak, že se dopouští smilstva duchovního, protože více miluje manželku než Pána Ježíše Krista, ženicha své duše, který říká: „Kdo miluje otce nebo matku nebo manželku víc nežli mne, není mne hoden." 104

Nepodezírej také neoprávněně svou manželku, pokud nemáš zjevné důkazy.

Zhřešíli tvá manželka, potrestej ji mírně bez skandálu. Bude-li se zpěčovat, k čemuž snad nedojde, ztrestej ji proutkem, ale ne holí. A měj se na pozoru, aby tě nespoutala a neodvedla podobně jako Delíla Samsona a nepředala tě Pelištejcům, tvým nepřátelům, tedy dáblům, poté co by ti vytrhla sedm vlasů, v nichž spočívala vítězná síla, ${ }^{105}$ to jest zbavila by tě sedmi darů Ducha svatého, kterými máš přemáhat nepřátele. Nebud' si jist sám sebou, že tebe přece žena nemůže oklamat, poněvadž nejsi moudřejší než Adam a Šalomoun ani silnější než Samson ani zbožnější než David, které oklamala žena. Proto se říká:

Adama, Samsona, Šalomouna i Davida krále,

ty všechny svedla žena: je před ní snad bezpečný někdo? ${ }^{106}$

Střez se tedy, abys nikdy nenaslouchal ženě v čemkoliv, co by bylo proti přikázání Božímu. Vždyt Adam, Šalomoun a jiní jí popřáli sluchu: a kdo z nás si vůbec může představit, co kvůli tomu vytrpěli a jak budou někteří trpět věčně? Amen.

Přijmi, Roberte, tyto mé řádky, a přijmi je vděčně, nebeských věcí se drž a plně se odevzdej Bohu,

který ti dokáže dát jak krásnou tak dobrou ženu, potlačí palčivost touhy a nakonec propůjčí cudnost. ${ }^{107}$

$1021 \mathrm{Te} 4,4$.

103 Hier., Adv. Iovin. 1, 49.

104 Mt 10, 37.

105 Srv. Žd 16, 4-22.

106 Walther (1963: pp. 519, 520); Walther (1959: p. 502). Překlad Jana Nechutová.

107 Překlad Jana Nechutová. Jako v př́padě čtyřverší, srv. pozn. 61, i zde v textu následují vysvětlivky k jednotlivým slovům ve verši: drž se $=\mathrm{v}$ duchu i v činech; věcí $=$ slov, potlačí $=$ tedy v tobě i v ženě, palčivost $=$ chtíč, touhy $=$ vášně, $[\mathrm{zmůže}=$ může $-\mathrm{v}$ latinské verzi odpovídá výrazům quit $=$ potest , přičemž české přebásnění užívá jiné formulace]' propůjčí = dá, cudnost = manželskou zdrženlivost. 


\section{Bibliography}

Bartoš, F. M., \& Spunar, P. (1965). Soupis pramenů k literárni činnosti Jana Husa a Jeronýma Pražského. Praha: Historický ústav ČSAV.

Erben, K. J. (Ed.). (1868). Mistra Jana Husi Sebrané spisy české (Vol. III). Praha.

Flaccius Illyricus, M. (Ed.). (1558). Ioannis Hus et Hieronymi Pragensis, confessorum Christi Historia et Monumenta (Vol. II.; f. 100r-104v). Norimbergae: Officina Ioannis Montani \& Ulrici Neuberi [retrieved 23.04.2018 from http://knihomol.phil.muni.cz/dl/oldbooks/monumentorvm-ioannis-hvs-1558].

Flajšhans, F. (1898). Přízvučné veršíky Husovy. Časopis Českého muzea, 72, 230-233.

Flajšhans, F. (1934). Traktáty Husovy a Kronika Vavřincova. Listy filologické, 61, 54-66.

Král, J. (1893). O prosodii české. Listy filologické, 20, 60-62.

Král, J. (1898). Přízvučné verše Husovy. Listy filologické, 25, 365-384.

Krmíčková, H., \& Nechutová, J. et al. (Eds.). (2016). Magistri Iohannis Hus Constantiensia. Turnhout: Brepols.

Mistr Jan Hus: Drobné spisy české (1985). (Magistri Iohannis Hus Opera omnia, IV; pp. 297-311). Praha: Academia, nakladatelství Československé akademie věd [ed. J. Daňhelka].

Molnár A. (1958). Hus' De matrimonio and Its Waldensian Version. Communio Viatorum, 1(2-3), 142-157.

Molnár, A. (1959). Husův kostnický spisek De matrimonio a jeho valdenské zpracování. Listy filologické, 82(1), 86-91.

Nováková J. (1966). Staročeský hexametr s přihlédnutím k hexametru novočeskému. In J. Levý (Ed.), Teorie verše (Vol. I; Spisy Filosofické fakulty University J. E. Purkyně, 107; pp. 195-201). Brno: Universita J. E. Purkyně.

Novotný V. (Ed.). (1920). M. Jana Husi korespondence a dokumenty. Praha: nákladem Komise pro vydávání pramenů náboženského hnutí českého.

Svoboda, M. (Transl.), \& Flajšhans, V. (preface and annotation). (1904). Mistra Jana Husi sebrané spisy, sv. V: Spisy čské (Vol. 2). Praha: nákladem Jos. R. Vilímka.

Vidmanová-Schmidtová, A. (1965). Husovy hexametry. Listy filologické, 88, 158-175.

Walther, H. (Ed.). (1959). Initia carminum ac versuum medii aevi posterioris Latinorum. Göttingen: Vandenhoeck \& Ruprecht.

Walther, H. (Ed.). (1963). Proverbia sententiaeque latinitatis medii aevi, Teil 1: A-E. Göttingen: Vandenhoeck \& Ruprecht.

Mgr. Soňa Hudíková, Ph.D. / 75531@mail.muni.cz

Department of Classical Studies

Masaryk University, Faculty of Arts

Arna Nováka 1, 60200 Brno, Czech Republic 
Mgr. Jana Malá, Ph.D. / janafuksova@mail.muni.cz

Department of Classical Studies

Masaryk University, Faculty of Arts

Arna Nováka 1, 60200 Brno, Czech Republic 
